\title{
FROM REVOLUTION TO RESISTANCE: A STUDY ON THE DISCURSIVE DEMISE OF THE EGYPTIAN ARAB SPRING
}

\author{
ALEXANDER BOGOMOLOV
}

\section{Introduction}

The recent Egyptian revolution of January 25, 2011 was widely perceived as different from those of the old age, particularly, due to an innovative use of social networks and modern electronic media as instruments of empowerment and mobilization, which turned a protest rally in in Cairo's Tahrir Square into a multimodal mass communication event. Egyptian revolutionaries, who picked up the torch from the successful Tunisian antecedent, had thereby inaugurated the so called Arab Spring a series of anti-government uprisings and protests across the Arab countries. The word spring (rabī') metaphorically signified renewal and breakaway from the past. International media eagerly and enthusiastically embarked on the production of a media story of democratic change sweeping all over the Middle East. Not only the left-leaning activists, but sober policy makers in the leading Western democracies, for all their trademark cautiousness, were operating on an essential similar reading of the Arab Spring ${ }^{1}$. However, should the enthusiastic supporters of the Egyptian revolution abroad be able to understand the native language and willing to listen, they would probably find the verbal manifestation of this highly ingenious and unu-

\footnotetext{
${ }^{1}$ For a brief account of early EU's response to the Tunisian and Egyptian revolutions, cf. Bremberg, N. 2016. "Making sense of the EU's response to the Arab uprisings: foreign policy practice at times of crisis". European Security 25: 4, 423-441, DOI: 10.1080/09662839.2016.1236019, pp. $430-432$.
} 
sually massive protest movement astonishingly conservative, when it comes to the beliefs and knowledge bases embedded in it.

The discourse of the revolution was built around a coherent set of concepts, some of which we have analyzed in a series of previous publications. This conceptual framework included many concepts that either were overtly Islamic or, though appearing superficially lay, were in fact linked intrinsically to the religious and religiously inspired ideological discourses. The discourse of the revolution had been set in motion by a dynamic semantic structure representing the scenario of the Revolution as seen by its participants and sympathizers, which we henceforth will refer to as revolutionary narrative. This revolutionary narrative was rather simple: it represented the Revolution as purposeful forward-going movement of the Egyptian People powered by the People's Will (Irādat aš-ŠA'B) and aiming at bringing down the State of Injustice (Dawlat az-ZULM) ${ }^{2}$, whose defeated henchmen $\left(\mathrm{FULU}_{\mathbf{U}}{ }^{3}\right.$ ) had to be marginalized (iqșā') cleared off (tațhīr), punished and thereby the innocent blood of the martyrs of the revolution (Šuhadā' at-Tawra) and the poor and oppressed (Maẓlūmūn), who suffered from injustice (ZULM) be avenged through retaliation (QIȘĀS $)^{5}$. In each particular text instantiating the revolutionary discourse one may find elements of this narrative with the whole variety of texts complementing each other in recreating the story of the Revolution over and over again. The narrative was designed to provide a sense of destination to multiple human efforts collective and individual and helped people make sense of the messy flow of events.

While our previous publications aimed at describing core elements of the revolutionary discourse as it normally functioned, our focus in the present study will be on what happens at the time of its imminent collapse. While instances of the revolutionary discourse bearing its definitive features as described above could be traced even to the early president Sisi period (2014), since 2013 the Egyptian political life took a dramatic U-turn, which made the triumphalist revolutionary narrative suddenly irrelevant and the dominant position that the pro-revolution voices had on the Egyptian media scene impossible to sustain. The defeat of the revolutionaries, however, had not affected an immediately rise of a new type of discourse, and even

\footnotetext{
${ }^{2}$ For a detailed analysis of this concept cf. Bogomolov, A. 2016. "A necessary evil: the conept of Zulm in Arab political discourse and its historic roots". Scripta Neophilologica Posnaniensia XVI. 7-39.

${ }^{3}$ For a detailed analysis of FULŪL (lit. notches as on a sword, debris of defeated army, which in the revolutionary discourse of 2011 became a preferred term for political opponents) cf. Bogomolov, A. 2014. "Constructing political other in the discourse of the Egyptian Arab Spring". Scripta Neophilologica Posnaniensia XIV. 7-31.

${ }^{4}$ Arabic verbs cited here in the form of mașdar (verbal noun) represent frequent collocations with nominations referring to the opponents of the revolution in the Egyptian revolutionary discourse.

${ }^{5}$ We have analyzed QIȘĀṢ (including the significance of Blood) in Bogomolov, A. 2015. "An eye for an eye and the struggle for power in the discourse of the Egyptian Arab Spring". Scripta Neophilologica Posnaniensia XV. 13-33.
} 
though in reality the military appeared to have won the battle for power, their new authoritarian regime still had long way to go in winning the legitimacy and adjusting the public discursive domain to its needs.

\section{The collapse of the revolutionary narrative}

The emergence on the political scene of a massive protest movement Tamarrud (Rebellion) ${ }^{6}$ in June 2013 signified a profound split in the Egyptian revolutionary camp $^{7}$. On the discursive plane it meant that the signifier $\underline{t} u w \bar{a} r$ (revolutionaries) now had not one but several conflicting referents. The Tamarrud movement affectively paved the ground for the military coup of 3 July 2013, which overthrew Egypt's first democratically elected president. In the aftermath of the coup, many activists who participated in January 25 revolution were thrown into jails or killed on the streets of Cairo during the Muslim Brotherhood-led anti-coup protests. These developments affected change in the scheme of power relations, and the one embedded in the revolutionary narrative and reflected in such concepts as FULŪL, which depicted counter-revolutionary forces as a weakened and defeated enemy, now also was at odds with the new political reality. The offensive modality of the revolutionary narrative suddenly became irrelevant and those voices in the public discussion domain that remained defiant in their support of the president Mursi had to re-group and re-formulate their public discourse, while the 'revolutionary youth' of Tamarrud were even more confused when their leaders had been also arrested in the wake of the coup over violation of a newly adopted anti-demonstrations law ${ }^{8}$. Those who remained defiant in the face of the coup projected their protests as a continuation or completion of the original January 25 revolution, hence their new self-identification as mukammilūn (completers). An anti-coup Muslim Brotherhood driven protest movement emerged under the banner of the National Alliance in Support of the Legitimacy (at-taḥāluf al-wațan̄ li-da'm aš-šar'̄ya). The word šar'̄̄ya (legality, legitimacy) thus became a key marker of the language of the Muslim Brotherhoodled protests. Struggle for Legitimacy (̌̌ar'îya) and against the coup (inqilāb) now became the lead theme of a new narrative, which replaced the old triumphalist narrative of revolution for many of those who still continued to call themselves Revolutionaries ( $\underline{\mathrm{t} u w \bar{a} r}$ ).

\footnotetext{
${ }^{6}$ The movement aimed to force president Mursi to resign and call snap elections by collecting 15 million signatures by 30 June 2013, the one-year anniversary of Mursi's inauguration, and claimed to have collected over 22 million signatures in support of these demands.

${ }^{7}$ The Tamarrud had effectively brought to a head a process, which some local observers described to us as a 'great secular - Islamist split', which had been particularly aggravated during Muslim Brotherhood affiliated president Mursi rule.

${ }^{8} \mathrm{http}$ //www.un.org/apps/news/story.asp?NewsID=46609\&Cr=egypt\&Cr1=\#.WI9FwdJ95dg
} 


\section{Going global... and more Islamic}

A violent crackdown by the coup authorities on a massive sit-in camp in Rābi'a al-'Adawiya square in Cairo, which for its participants represented a flashback of January 25, 2011 Tahrir square protests, marked a turning point in the course of the post-revolutionary history. In these new circumstances, which to many meant the victory of counter-revolution (at-tawra al-mudadda) and the comeback of the State of Injustice (dawlat az-zulm) ${ }^{9}$, the old revolutionary narrative became altogether irrelevant even for the Islamists, who eagerly adopted it in the aftermath of Mubarak's downfall and made it part of the official discourse during the president Mursi's brief rule. For the defiant supporters of the Muslim Brotherhood the events of Rābi'a had now largely eclipsed in their collective memory and political symbolism the January 2011 Tahrir square protests. The more recent dramatic event has come to be referred simply as Rābi'a, and the date of a violent crackdown on the sit-in rally has been since commemorated every year. The events of Rābi'a have inspired a four-finger salute, which became a new symbol of defiance for the supporters of the deposed president Mursi and the Muslim Brother$\operatorname{hood}^{10}$, for rābi'a originally means an ordinal number 'forth' in Arabic ${ }^{11}$. In contrast to 2011 Tahrir square sit-in, which in the discourse of January 25 revolution was interpreted as a metaphor of national unity, the Rābi'a events were framed by Muslim Brotherhood supporters in a global pan-Muslim, rather than a national perspective, cf.:

rābi'a hiya ramz al-ḥurriya, rābi'a hiya mahnạ̣̄ li-wilādat ḥarakat ḥurriya wa 'adāla jadīda, rābi' a hiya bašāra li-wilādat al-'ālam al-jadīd, rābi'a hiya burūz al-muslimīn min jadīd fĩ as-sāḥa ad-duwaliya, rābi' a ta'nī al-'adāla wa al-ḥurriya wa ar-rạ̣ma, rābi'a hiya man inhārāt amām a' tābihā al-qiyam al-ġarbiya az-zā' ifa ${ }^{12}$

Rābi'a is a symbol of freedom, Rābi'a is a travail for the birth of a new movement of freedom and justice, Rābi'a is a good news of the birth of a new world, Rābi'a is the appearance of the Muslims again on the international scene, Rābi'a means justice and freedom and mercy, Rābi'a is [she] who the false Western values have fallen on her doorstep.

\footnotetext{
${ }^{9}$ On the significance of this notion in the revolutionary discourse cf. Bogomolov, A. 2016. "A necessary evil: the conept of Zulm in Arab political discourse and its historic roots". Scripta Neophilologica Posnaniensia XVI. 7-39.

${ }^{10}$ The symbol represents a hand with four fingers raised and the thumb drawn across the palm; graphically the symbol is often styled as a rectangular black on yellow road warning sign.

${ }^{11}$ The square is a site of a mosque dedicated to an $8^{\text {th }}$ cent. CE Muslim female 'saint' and Sufi mystic, who was so named for she was the fourth child in her family.

${ }^{12}$ From the text of a proclamation called 'What is Rābi'a?' (mā hiya Rābi'a) - http://vb.3dlat. net/showthread.php?t=189028
} 
Obviously, the text draws alludes to the key slogan of January 25 revolution Bread, Freedom, Social Justice, Human Dignity ${ }^{13}$ - but it also reinforces its Islamic connotation by augmenting a religious concept of rahma (mercy).

\section{Key elements that survived from the revolutionary discourse}

The decline of the original revolutionary discourse, however, does not mean that all its elements have become irrelevant. The theme of RETALIATION (QIȘĀS) continues even now although the context has changed. Cf. the following rejoinder attributed to a prominent Muslim Brotherhood member:

bi-ḥasb ḥamza zawba 'aḥad qiyādāt al-ihwwān fī al-ḥārij wa allad̄ī aḍāf anna: 'al-mușālaḥa laysat bi-yad ayy fașīl, bal bi-yad aš-ša'b wa awliyā' ad-dam (duī al-qatlā) wa ahālī al-mu' taqalīn (as-sujanā') wa al-mușābīn wa al-mušarradīin ${ }^{14}$

... according to Hamza Zawba, one of the leaders of the Brotherhood abroad, who added that: 'the reconciliation is not in the hands (lit. hand) of whatever group, but in the hands of the people and the next of kin (relatives of the slain - A.B.) and families of those in custody (the prisoners) and the injured and the displaced

The Muslim Brotherhood functionary clearly implies the power of the next of kin to demand QIȘĀS for their slain relatives according to the Sharia norms ${ }^{15}$. By extending these powers to the entire Egyptian people the speaker is replaying the same rhetorical ruse as the revolutionaries when they tried to challenge the authorities by invoking the powerful concept of retaliation. The topic of mușālaha (reconciliation), which became a prominent theme of debate between the government, the civil society and the families of activists incarcerated in the aftermath of the coup, represents another reference to the traditional norms. According to Muslim custom, one way of peacefully settling a dispute between the two conflicting sides that emerge in the aftermath of a violent crime, which are in a prototypical situation represented by the families of the victim and the offender, - is through achieving an agreement called sulha (a derivative of sulh 'peace'). The reciprocal $6^{\text {th }}$ form muṣālaha, which in English translation is usually rendered as 'reconciliation', essen-

\footnotetext{
${ }^{13}$ Also, of course, to the name of the Muslim Brotherhood's political wing - Freedom and Justice Party.

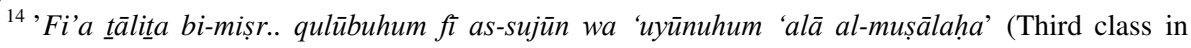
Egypt: their hearts in prisons and their eyes on the reconciliation). Huffington Post Arabic, 28 November 2016 - http://www.huffpostarabi.com/2016/11/28/story_n_13278628.html

15 "And whoever is killed unjustly, we have given his executor power, but let him not exceed limits in killing. Indeed, he has been supported" (Quran 17: 33) - cf. Bogomolov, A. 2015. "An eye for an eye and the struggle for power in the discourse of the Egyptian Arab Spring". Scripta Neophilologica Posnaniensia XV. p. 29.
} 
tially means a mutual sulha. Sulha. Such settlement is intended to avoid a chain of mutual relations between the affected clans ordinarily by way of letting the offender's relatives pay an agreed amount of material compensation (diya) for the victim's blood, a practice meant to be a substitute for QIȘĀS. The recent emphasis on mușälaha, therefore, throws light on the policy of massive arrests in the aftermath of the coup: authorities were effectively creating a bargaining chip for the subsequent negotiations acknowledging thereby the people's QIȘĀS, which represented a key element of the revolutionary discourse, as indeed a formidable challenge to their power, just as we have concluded in our analysis before ${ }^{16}$.

In the hot public debate pro and contra mușālaḥa the continued suffering $(m u ' \bar{a} n \bar{a})$ of the prisoners is clearly weighed against the imperative of QIṢĀṢ:

țālamā laysat ladayka ru'ya li-istirdād ḥaqq aš-šuhadā' wa lā li-ḥurūj al-mu'taqalīn fa-laysa min ḥaqqik an ta'tarị̣ 'alā ayy mubādara yakūn fīhā hall li-ḥurūj al-mu'taqalīn mabda'iyyan ${ }^{17}$

As soon as you don't have a vision for the reinstating the rights of the martyrs (i.e. the right of the next of kin to avenge their blood - A.B.) and neither for the release (lit. exit) of the prisoners, you don't have the right to object to any initative containg the solution for the release of prisoners in principle

The revolutionary power of the imperative of QIȘĀṢ is undermined in the official discourse of Sisi's Egypt by replacing its referents. It is now mainly servicemen, either as casualties of the war on Islamist militants in Sinai or victims of alleged terrorist acts in Cairo, who are called martyrs (šuhadā') and whose blood now calls for QIȘĀṢ in the official media. QIȘĀṢ, on the other hand, has now become a central theme in the public messages of various clandestine militant groups, which take responsibility for sporadic acts of terror targeting government officials; one such group even calls itself Ḥarakat al-QIȘĀṢ (Retaliation Movement) ${ }^{18}$. The official media are also exploiting the same concept and even the style that used to be characteristic of the revolutionary discourse in waging their verbal war on the militants, cf. a newspaper headline: ahālì al-mahmmūdiya yuțālibūna bi-l-QIṢĀṢ min harakat hasm al-irhābiya ${ }^{19}$ (citizenry of Madmudiya are demanding retaliation against the terrorist Resolve Momevent). QIȘĀS has thus become a contested notion in this

\footnotetext{
${ }^{16}$ Ibid.

${ }^{17}$ Ibid. a Facebook post cited as an apparently strong argument in favor of mușālaha; consider also the subtitle of the appropriate part of the article - mușālaha muqābil al-hurriya (Reconciliation in exchange for freedom), in which reconciliation is juxtaposed to what appears to be an undisputed value, implying that reconciliation is in fact a negative thing - a forced concession, a moral sacrifice or a least evil solution.

${ }^{18}$ For brief reference cf. an article on the detention of members of Retaliation Movement and another group called Ḥarakat Ḥasm (Resolve Movement) - https://goo.gl/YCj8yN

${ }^{19} \mathrm{http}: / /$ www.elbalad.news/2436635
} 
polemic with the pro-government side, which depicts what the militants present as acts of retaliation as terrorism (irhāb). The militants, on their part, continue to describe the government's retaliatory and preventive violence as ZULM. It is the powerful cultural meanings underlying the concept and their status of a shared value that fuel this heated argument.

To be sure, while the revolutionary narrative prevailed in the public discussion for a period of about three years, there always had been a counter narrative, generated by the acolytes of the Ancien Régime whom the revolutionaries called FULŪL. While detailed analysis of this counter narrative is outside of the scope of this study, data available to us suggests that, as it usually happens in the context of contentious political discourses, this counter narrative uses various word games and puns to construct a meta-cultural commentary on key value concepts of the target narrative. One characteristic case in point is use of the word haräyib (ruins), modeled on the syllabic structure of the word yanāyir (January) ${ }^{20}$, which had been used as a common short name for the January Revolution (tawrat yanayir). To the best of our knowledge, such vernacular mocking language has not penetrated the official media discourse, but had certainly gained more ground in the more colloquial forms of public discussion in the aftermath of the $\operatorname{coup}^{21}$. On a more formal plain, similar to the situation in Ukraine in the aftermath of the Orange revolution of 2004, there always had been and continues to be an expert discussion on whether or not January 25 had indeed been a revolution, with those who deny the applicability of the term suggesting alternative definition such as uprising ("ișyān) or even coup (inqilāb). While voices of those in denial had been weakened or hushed, when the revolutionary narrative prevailed, in the wake of the coup they became more confident. Nowadays, according to local observers, the word revolution (tawra) in reference to January 25 events is being cautiously avoided in public discussion even by many of those, who had eagerly identified with revolution, and replaced by alternative terms, often simply referred to as ahdāt yanā'ir (events of January). The popular uprising of June 2013 that led to the ousting of president Mursi was also presented as another Egyptian revolution or as the completion of the one that began in January 25, again diluting the reference scope of the original revolutionary narrative. Those, who remained defiant immediately took to calling it coup, which had also contributed to undermining the conceptual pact ${ }^{22}$ among a wide cross-section of the Egyptian society that emerged in early 2011 in the wake of Tahrir square sit-in and the

\footnotetext{
${ }^{20}$ It is effectively a contamination or an imperfect pun, for the discussion of this and other types of ludic transformations cf. Lennon, P. 2011. "Ludic language: the case of the punning echoic allusion". Brno Studies in English. Vol. 37, No. 1. p. 82.

${ }^{21} \mathrm{We}$ are grateful to our Egyptian informants for bringing this phenomenon to our attention.

${ }^{22}$ For the notion of conceptual pact cf. Clark, H.H. and A. Bangerter. 2004. "Changing ideas about reference”. In: Noveck, I.A. and D. Sperber (eds.). Experimental Pragmatics. p. 39.
} 
downfall of Mubarak regarding what is to be called revolution in the contemporary Egyptian context.

Another theme that did not go away and remained salient in the post-revolutionary discourse of defiance was dawlat az-ZULM (the State of Injustice). At the onset of pro-Mursi rallies in the aftermath of the coup the protesters even coined a specific chant designed to challenge the State of Injustice: 'umru z-zulm $m \bar{a}$ 'awwam dawla (col. Egyptian, never had ZULM established a state) ${ }^{23}$. In contrast to the revolutionary narrative, which depicted the revolution as a struggle of TUWĀR (revolutionaries) against FULŪL, it is now the State of Injustice itself that has become their powerful antagonist, and the revolutionaries are not the triumphant winners but victims of ZULM, their inactivity (and on the pragmatic plain, also an indirect invitation for the addressee to show compassion to them) is reflected in the use of such nominations as abnā' at-tawra (sons of the revolution) instead of $\underline{t} u w \bar{a} r, \mathrm{cf}$.:

wa 'indamā atahaddat 'an dawlat az-ẓulm fì al-maqāl al-awwal yalīh 'adad min al-maqālāt taḥt 'unwān dawlat az-ẓulm wa awwal man atahadda 'anhum hum abnā' aț-tawra al-mișriyya rufaqā̄' an-nidāl allad̄īna yata' arrạ̣ūna li-ẓ-ẓulm li-annahum arādū an yatahạaddū al-fasād wa al-istibdād allatī ta'î̌ūh miṣr 'alā madār as-sanawāt al-aḥīra

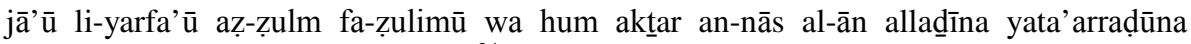
li-ž-ẓulm dāhil as-sujūn al-mișriyya ${ }^{24}$

And when I talk about the state of injustice in the first article [which is] followed by a number of articles under the heading 'The State of Injustice', the first who I talk about are the sons of the Egyptian revolution, comrades in struggle, who are subjected to ZULM for they wanted to challenge the corruption and despotism, which Egyp is living through over the course of last years, [they] came to eliminate (lit. raise) ZULM and were wronged (subjected to ZULM) and they [are now] the ones who are subjected to ZULM the most in the Egyptian prisons.

Standard metaphors of personification are deployed to depict the State of Injustice as monolithic entity, often a carnivorous beast, e.g. tajdīd habs as-salāmūnī yu'akkid anna dawlat az-zulm lam tašba' min laḥm abnā' mișr ba'd (the extended [term of] detention for Salamuni proves that the State of Injustice is not sated yet with the flesh of the sons of Egypt). The renewed theme of the State of Injustice brings back the unending debate over the role of religion as a source of legitimacy:

\footnotetext{
${ }^{23}$ http://old.egyptwindow.net/news_Details.aspx?News_ID=43297

${ }^{24}$ Muhammad 'Awwād. Dawlat az-Zulm (The State of Injustice), right at the time of writing the article suddenly disappeared from the site www.mazlom.com (mazlom is a typical Arab transliteration for mazlüm 'oppressed, wronged, victim of ZULM and the site has been obviously designed specifically to highlight the government's oppressions against revolutionaries) and could only be retrieved in a cached form - https://goo.gl/zfXIIR
} 
wa gadan sa-takūn nihāyat al-inqilāb wa taqayyud al-ḥurriyāt wa az-zuulm li-anna dawlat aẓ-zulm sa-tazūl ḥattā wa law kānat muslima wa dawlat al-'adl sa-tabqā hnālida ḥattā wa law kānat kāfira wa li-anna hā'ulā' al-mujrimīn al-qatala as-saffāhīn laysū miṣriyīn wa lā muslimīn fa-dīnuhum wa wațanuhum as-sulța wa al-māl illā anna naṣru aḷạhi qarīīb

And tomorrow will be the end of the coup and the restriction of freedoms and ZULM for the State of Injustice will disappear if even it were [a] Muslim [one] and the State of Justice will remain eternal (lit. immortal) even if it were [an] infidel [one ${ }^{26}$, for these criminals, murderers, slaughterers are not Egyptians and neither Muslims, for their religion and their homeland is power and money, but Allah's victory is near

The manner, in which the State of Injustice is supposed to end, i.e. it will 'disappear' and the 'eternal' nature of the State of Justice, which will come in its stead, sound as a flashback of the REVOLUTION as MIRACLE frame, characteristic for the revolutionary narrative, which we discussed elsewhere ${ }^{27}$. The immediacy of the aspired relief from ZULM, which this segment implies, is also reminiscent of the theme of speediness in relation to QIȘA ${ }^{28}{ }^{28}$, pointing to a common cultural premise underlying such beliefs. The segment also reflects the notion of Muslim state as that, whose rulers are Muslims, which is apparently shared by both the ruling elite in its attempt to legitimize their grip on power and the defiant activists of a clearly Islamist persuasion.

Unlike QIṢĀṢ, this theme, in view of a strong cognitive link that exists between the concepts of ZULM and POWER, appears to be difficult or even impossible to reappropriate for the newly re-established authoritarian regime. As a search item on Google Trends dawlat az-zulm peaked on September 2013 coinciding with couple weeks after the violent crackdown on pro-Mursi protest rallies in Rābi'a al-'Adawiya square and November 2014, days after another violent crackdown on student protests of mid-October $2014^{29}$. On 30 November, 2016 the Google search

\section{${ }^{25} \mathrm{https}: / /$ goo.gl/EP2isD}

${ }^{26}$ The notion of an infidel state here, used notably as a counterfactual, is of course merely a rhetorical foil or a reluctant concession to the idea of civil state (dawla madaniyia), which reflects a hot political debate among secular and Islamist activists in the aftermath of the downfall of Mubarak.

${ }^{27}$ REVOLUTION as MIRACLE cognitive schema is characteristic of all strands of the Egyptian revolutionary discourse; the schema represents REVOLUTION as an almost instantaneous change from a bad condition to a good one, cf. [they] woke up from their sleep to find that the state of injustice had fallen with no [possibility of] return (saḥaw min nawmihim wa-ktašafū anna dawlat az-ẓulm qad saqațat ilā gayr ruj'a). For details cf. Bogomolov. A. 2015. "Makers of revolution: the concept of ŠABĀB (YOUTH) in the discourse of the Egyptian Arab Spring". Skhodoznavstvo No. 69. 3-28.

${ }^{28}$ Cf. Bogomolov, A. 2015. "An eye for an eye and the struggle for power in the discourse of the Egyptian Arab Spring”. Scripta Neophilologica Posnaniensia XV. p. 19.

${ }^{29} \mathrm{https}: / /$ www.google.com/trends/explore?date=all\&q=\%D8\%AF\%D9\%88\%D9\%84\%D8\%A9\%20 $\% \mathrm{D} 8 \% \mathrm{~A} 7 \% \mathrm{D} 9 \% 84 \% \mathrm{D} 8 \% \mathrm{~B} 8 \% \mathrm{D} 9 \% 84 \% \mathrm{D} 9 \% 85$ For coverage of student protests crackdown see 'Egypt universities rocked by fresh protests', Aljazeera website, 13 October 2014 - http://www.aljazeera.com/ news/middleeast/2014/10/egypt-universities-rocked-fresh-protests-20141013135357582738.html 
for dawlat az-zulm phrase returned about 149,000 results for the past year alone, which suggests a high salience of the theme in public discussion. On the Google search the phrase most often appears as part of a vocative expression $y \bar{a}$ dawlat $a z-z u l m$ ( $\mathrm{o}$, the state of injustice) and the phrase that has become idiomatic in the revolutionary discourse dawlat az-zulm sā'a, dawlat al-haqq ilä qiyām as-sā'a (the state of ZULM [is for] an hour, the state of truth/justice [is] until the doomsday), often abridged to its first part dawlat az-zulm $s \bar{a}^{\prime} a$ (the state of ZULM [is for] an hour). While the former usually introduces emotionally charged invectives, lamentations and threats leveled at the military-led post-Mursi government, the latter is used as an encouragement to fellow revolutionaries. In 2013 in the aftermath or the coup invectives addressed to the State of Injustice have even become a theme of popular poetry, such as the following qași $d^{30}$ by Maḥmūd ibn Ibrāhīm aș-Ṣabbā $\dot{g}^{31}$ titled Yā dawlat az-zulm, isma'̄ (o, state of injustice, listen):

yā dawlat az-zulm, isma'ī āna al-awān li-tadma'ī (...) at-țiflu māta bi-ḥanqa wa aš-šayḥu māta bi-midfa' (...) al-'adlu kunti makānahu wa az-zulmu fỉki a tafza 'î̀? $?^{32}$

$\mathrm{O}$, state of injustice, listen, the time has come for you to weap (...) the child died of strangling and the old man died of a cannon [fire] (...) you have replaced the justice (lit. the justice you were in place of it) and ZULM is in you, don't you fret?

A popular hashtag on Twitter 'Mursi is still the president ${ }^{33}$ continues to promote the idea that president Mursi will return to bring the State of Injustice to its end. The idea sounds as a flashback of a messianic myth, which impression is reinforced by the inclusion of devotional elements invoking the Quranic story of the miraculous salvation of Jonas ${ }^{34}$, cf.:

yā aḷạh man hạafiẓta yūnis fì baṭn al-ḥūt, yā a!̣̣̄h iḥfiz 'abdaka muḥammad mursī mi aydi az-ẓālimīn quạāt al-askar ${ }^{35}$

o, Allah, [you] who have preserved Yunis (Jonas - A.B.) in the belly of the fish, o Allah preserve your slave Muhammad Mursi from the hands of the unjust (oppressors) judges of the military

Here is another characteristic segment discussing Mursi's plight attributed to a prisoners' rights activists:

\footnotetext{
${ }^{30}$ A classical form of Arab poetry.

${ }^{31}$ This author is described as young preacher and sheikh (ad-dā'iya aš-šābb šayhn) cf. http://www. forsanhaq.com/showthread.php?t=367238

${ }^{32}$ The poem was posted on the web on 21 August, 2013, days after the violent crackdown on the anti-Mursi protests, for the full text cf. http://www.forsanhaq.com/showthread.php?t=372985

33 مرسي_لسه_الريس (Mursi is still the president); the hashtag was active at least through mid-2016.

${ }^{34}$ Jonas' story of captivity in the belly of a fish and miraculous salvation is recounted in Quran 37: $139-148$.

${ }^{35}$ http://www.fj-p.com/Our_news_Details.aspx?News_ID=97163
} 
wa qālat sārra muḥammad: wa law ijtama' ū 'alā an yuḍirrūka lan yuḍirrūka illā bi-šay ${ }^{\text {,in }}$ qad katabahu alḷāh 'alayk, liannahu 'așruhu kān 'aṣr al-ḥurriyāt.. lam yaqșif qalam ${ }^{a n}$ wa lam yaḥbis șuhufiy ${ }^{a n}$ wa qālat asmā' bi-'awdatika tantahī dawlat az-ẓulm wa yantah̄̄ al-inqilāb al-ḡāšim az-za'īm murī ra' '̄s̄ì wa aftahir li-l-ahrār faqat ${ }^{36}$

And Sarra Muhammad said: and if [they] have agreed on harming you, [they] won't harm you if not by something that Allah had written upon you, for his time (probably in reference to the rule of president Mursi - A.B.) was the time of freedoms.. [he] had not broken a pen and not imprisoned a journalist and Asma said: with your return the state of injustice will end and the oppressive coup will end, the leader Mursi [remains] my president and I am proud of the freemen only.

It is notable that Mursi here is praised for what he didn't do rather than for something that he actually did, effectively for not being a Tyrant (Zālim, Ṭāgiya), which invokes the concept of ZULM as the key theme of the Revolution. The power of the divine ordainment in the post-coup discourse of defiance is juxtaposed to the power of mundane authorities and the religious myth as a counter narrative to that of the official discourse of the oppressive regime. The post-revolutionary discourse of defiance, hence, continues to find a source of inspiration and empowerment in the same conservative religious values as in the original revolutionary discourse. Religious theme in the context of an obvious retreat (if not a complete defeat) of the revolution, as the above cited segments suggest, are mainly invoked in support of promises or threat, i.e. effectively as counterfactuals, meaning that as an instrument of discursive empowerment they are not as powerful as the demands for retaliation had been at the peak of the revolution.

\section{Arab discourse of Resistance as the Revolution's fallback symbolic resource}

The revolutionaries, who remained defiant in the aftermath of the coup, tried to hold on to whatever was left of their diminishing resources, including the discursive ones, and mobilize more support by stepping up tactics of protest that proved efficient during the January 25 revolution of which the sit-in protest camp in Rābi'a was the most characteristic example. On the discursive plain, the new discourse of defiance used more of the same religious rhetoric but also tapped on other sources, such as the powerful Arab discourse of Resistance, originally developed by Arab nationalist and leftist movements and hardened through decades of confrontation with Israel and the West. The Egyptian Muslim Brotherhood supporters were not the first among the Islamist movements to tap on this discursive powerhouse, as other re-

\footnotetext{
${ }^{36}$ http://www.fj-p.com/Our_news_Details.aspx?News_ID=97163
} 
gional Islamists groups, such as the Palestinian Hamas and the Lebanese Hizbullah, had long ago adjusted the once strictly secular discourse of Resistance to their needs.

As any well-developed strand of political discourse, the discourse of Arab Resistance has its characteristic set of concepts and elaborate narratives, reflecting a history of ideological influences and reflective engagement with turbulent political events. But, just as the Egyptian revolutionary discourse, at its core it has a basic narrative structure, whose underlying schema is relatively simple: it could be described as struggling against an overwhelming force. As modern as the discourse of Resistance may seem, it is no less culturally idiosyncratic and grounded in deeply embedded cultural premises similar to the religious discourses that contributed to the January 25 revolutionary discourse. A thorough analysis of this discourse would go well beyond the scope and purpose of this study, we will, therefore, constrain ourselves below to the analysis of its single most important concept - S SUMŪD. The concept refers to what could be described as a key moral and physical quality or inner resource, which helps embattled militants resist an assaulting force more powerful than themselves. It is not accidental, therefore, that the concept, which we saw no trace of at the peak of the revolutionary discourse, was reclaimed by the defiant Egyptian revolutionaries, once they confronted an overwhelming opponent.

Although ȘUMŪD has now become a staple of political discourse all over the Arab World, for the Arab political mind it continues to be linked to a single place Palestine, the launchpad of the ideology and the discourse of MUQĀWAMA (RESISTANCE). Once the narrative of January 25 revolution had lost its spell, the remaining defiant protagonists of the revolutionary epic needed a new narrative of defiance that would help raise the morale and mobilize the loyal constituencies in the face of an overwhelming and often very violent force. The revolution's shattered manpower needed replenishment, and so did its symbolic arsenal. It does not appear to be accidental that the discourse of Resistance, which dominated Arab politics for decades, would come up as a useful resource base for the much needed symbolic reinforcement. Of the discourse of Resistance, it is the concept of SUMŪD that appeared to be particularly fitting the post-coup context in Egypt. ȘUMŪD is not merely the most salient among the concepts in the discourse of Resistance, but also the one that helps make sense of the rationale, sources of inspiration and the political practice of resistance to an overwhelming force, which, when projected on the Egyptian reality, helped structure the everyday reality of the ongoing protest and empower its participants.

During but even more so, after the violent crackdown, Rābi'a emerged as a key symbol of resistance to the coup while the concept of SUMŪD provided a clue to converting this dramatic and painful experience into a political asset, a source of inspiration and empowerment for the protesters. Rābi'a inspired both the main graphic symbol and the verbal slogans of the ensuing anti-coup movement. Here is an example of a chant used at rallies in 2014: rābi'a ramz aṣ-șumūd 'āšu rigāla wa 
$m a \bar{t} \bar{u}$ usūd (col. Eg. Rābi'a is a symbol of ȘUMŪD, [they] lived as men and died as lions) ${ }^{\mathbf{3 7}}$. The Muslim Brotherhood supporters in exile have even produced an operetta under the heading Rābi'a aṣ-ȘUMŪD (Rābi'a of ȘUMŪD), which premiered in Istanbul on the third anniversary of January 25 revolution and was broadcast via social networks ${ }^{38}$.

ȘUMŪD is found in collocation with at- $\underline{t} u w \bar{a} r$ (revolutionaries, def.) or $\underline{t} u w \bar{a} r$ (revolutionaries indef., usually, followed by a places name, e.g. garb al-iskandariya 'West Alexandria') ${ }^{39}$. Then comes the collocation șumūd aš-šabāb (ȘUMŪD of the youth) ${ }^{40}$, and șumūd šabāb (indef. \& place name or other Gen. attributive) ${ }^{41}$.

ȘUMŪD has also come to be firmly associated with the imprisoned and tormented president Mursi as his supposedly distinctive quality. The anti-coup posters were praising president Mursi for his ȘUMŪD: $a \check{s}$-ša'b yuhayȳ șumūd ar-ra'̄̄s (the people salute the president's ȘUMŪD). A newspaper title runs: raġm al qubdān assīsì yā'is amām șumūd ar-ra'̄̄s mursì ${ }^{42}$ (despite the [prison] bars, Sisi is desperate before president Mursi's ȘUMŪD). Another title, attributed to a seasoned oppositioners Ayman Nūrr ${ }^{43}$, says anā ahjal amām șumūd ar-ra'īs mursī (I feel ashamed confronted with president Mursi's ȘUMŪD) ${ }^{44}$. Here is more elaborate segment on Mursi's ȘUMŪD:

inna șumūd hād̄ā ar-ra'īs amām kull hādֵihi al-miḥān wa al-musāwamāt wa at-taḥqīqāt min qimmat al-haram hِayt kān ra'īsan ya'mur wa yanhā fī kull șagīì wa kabīr fī dawla

${ }^{37}$ A news article titled mutaẓāhirū al-qanțara bi-l-ismā' ’̄liya yahtafūn 'umru az-ẓulm mā qawwam dawla (Demonstrators of Qantara in Ismailia chanting: the injustice never strengthened a state) at an oppositional Nāfidat Mișr website, 3 October, 2014 the article reproduces a long list of chants used at the rallies - http://old.egyptwindow.net/news_Details.aspx?News_ID=43297

${ }^{38}$ http://www.fj-p.com/Our_news_Details.aspx?News_ID=99990 The 'operetta' actually represents a gala with several entertainers singing in a round in Arabic, Turkish, Spanish, English, Malay and Indonesian with the phrase rāba' aș-sumūd (col. Egyptian version of Rābi'a aṣ-Ṣumūd) repeated as a refrain - to listen cf. https://www.youtube.com/watch?v=XTok9d3-MEs

${ }^{39}$ Google search for the version of the phrase with definite form 35,300 results, while the version with indefinite returned 5,900 results as of 4 December, 2016, although we have limited our search, as usually, to the Egyptian segment of the web, the topic of many texts is Syria.

${ }^{40}$ For ŠABĀB [at-tawra] (the [revolution's] youth) as one of the protagonists of the revolutionary narrative cf. Bogomolov, A. 2015. "Makers of revolution: the concept of ŠABĀB (YOUTH) in the discourse of the Egyptian Arab Spring”. Skhodoznavstvo No. 69, 3-28.

${ }^{41} 14,400$ results on Google search for the version with def. form, as of 4 December, 2016, and 7,880 for the version with the indef. form.

${ }^{42}$ Published on 15 November, 2016 - http://www.fj-p.com/Our_news_Details.aspx?News_ID= 04801

${ }^{43}$ Chairman of al-Ġad (future) party, whose running against Mubarak in 2005 presidential elections ended with his imprisonment by the authorities.

44 The article was published on 21 September, 2016 - http://www.fj-p.com/Our_news_Details. aspx?News_ID=101911 
ilā insān lā yamlik min amr nafsihi wa gayrihi šay'an! ayy qahr wa ẓulm yaš'ar bihi hād̄ā $\operatorname{ar-rajul} ?^{45}$

ȘUMŪD of this president in the face of all these hardships, bargaining and examinations - from the top of the hierarchy as he had been president ordering and forbidding (an idiom meaning having an ultimate authority - A.B.) in all small and big [things] in the state - to a man [who] possesses nothing of his own affair or [that] of others (another idiom meaning powerless - A.B.)! What kind of subjugation and ZULM this man feels?

In collocation with Mursi comes out, what is not so obvious in other contexts but is nevertheless as important, - an intrinsic relation that there is between SUUŪD and the concept of POWER. STUMŪD is a power source for those in a weak position. ȘUMŪD is depicted as a force ${ }^{46}$ equivalent to the power of $\mathrm{ZULM}^{47}$ :

rābi'a ta' nī at-țabāt wa aṣ-ṣumūd țabāt ahl al-ḥaqq 'alā ḥaqqihim wa șumūduhum amām aẓ-ẓulm wa aṭ-ṭuggyān hādā at-tabāt laysa amr $^{\text {an }}$ hayyin ${ }^{\text {an }}$ wa lā sahl ${ }^{\text {an }}$ fa-lā yaṣhū al-insān min nawmihi yajid nafsahu tāāit ${ }^{\text {an }}$ șāmid ${ }^{\text {an }}$ bal hiya minna min alḷăh 'azza wa jalla

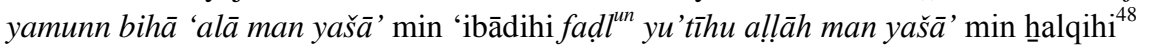

Rābi'a means firmness and ȘUMŪD, firmness of those who have right (lit. people of the right/truth) over their right/truth and their ȘUMŪD in the face of ZULM and tyranny, this firmness is not an simple thing and not an easy [one], and one does not wake up from his sleep to find himself firm and ȘāMid (act. part of $\sqrt{S M D}$ ), but [this] is a gift from Allah the Almighty and the Great [that] he bestows upon whoever he wishes among his servants, favor [that] he brings to whoever he desires among his creatures

The segment reflects an extraordinary tension that the religious mind must feel confronted with so much hope being invested in a concept that refers to the human inner powers, which for a religious mind constitute the divinity's exclusive domain, yet, unlike other key elements of the discourse of defiance is not grounded in neither normative, nor the devotional Islamic discourses. The dilemma is being resolved here with the help of an interpretative frame characteristic for religious discourses, which may be formulated as GOOD is GOD's GIFT. Through this interpretation the human capacity to sustain external pressure is granted a divine sanction and the divine power is invoked in its support.

\footnotetext{
${ }^{45}$ Op-ed article titled al-umma al-islāmiya tuhayyi șumūd ar-ra'̄̄s mursī (Islamic umma salutes president Mursi's ȘUMŪD) - http://old.egyptwindow.net/ar_print.aspx?print_ID=36558

${ }^{46}$ We use the term force here in a metalinguistic sense, as in Talmy, L. 1968. "Force dynamics in language and cognition". Cognitive Science 12, 49-100. ȘUMŪD is conceptualized as a force sufficient to keep in check the tendency of ZULM to advance.

${ }^{47}$ The absence of stable collocations with abnā (sons of either revolution or the Egyptian people), which we have noted above, is another evidence of this connection - it could be accounted for by ȘUMŪD's propensity to combine with nominations referring to active/powerful parties.

${ }^{48} \mathrm{http} / / /$ marsadpress.net/?p=15999
} 


\section{Conclusions}

Discourse is best understood as an act of communication involving multiple social actors. Social actors are not, however, speakers in the usual sense of the term, but groups or classes of people, which do not, strictly speaking, engage in anything similar to a conversation, even though discourse is sustained by what appears to be contributions of individual speakers. It is a communicative act mediated by social structures, which operates more as a repository of knowledge and remains active in as much as there remains a sufficient (socially significant) number of users, who both contribute to and tap on the symbolic resources that it contains. From a sociopragmatic perspective, discourse serves above all a social function of creating and maintaining consensuses and coherence of collective action. The narrative of the January 25 revolution reflected a consensus among multiple social groups regarding the meaning of Revolution, values that had inspired and driven them and, importantly, regarding their respective roles. The narrative of the revolution and its underlying conceptual framework resulted from a conceptual pact ${ }^{49}$ among a broad crosssection of the Egyptian society that emerged through their joint engagement in and support of the January 2011 Tahrir square protests, - an event, which became a key point of reference in the ensuing public debate. By 2013, with growing disagreement between various classes of revolutionaries, particularly, the secular and Islamist groups, and the changing power relations, this conceptual pact had shrunk and crumbled and the original broad consensus could not be sustained anymore. The transformation that affected the set of protagonists of the revolutionary narrative, described by local observers as the 'great secular - Islamist rift', occurred not in the language but in political reality, and resulted in the rise of several alternative voices and narratives supplanting the single revolutionary narrative. The collapse of a coherent and simple revolutionary narrative and the demise of the revolutionary discourse all together signified the (re)emergence of fault lines within the society, which could not fit anymore into the simplistic scheme 'PEOPLE vs. REGIME', underlying the original revolutionary narrative. When the revolutionary discourse collapsed, it did not do so in its entirety. Elements that went out of use were those that had referents in the immediate social setting, including social actors, the nature and the dynamics of the events, which changed dramatically in the aftermath of the coup. Elements that survived were those that represented beliefs and shared values embedded deeply in local culture. These elements, despite being contested when it comes to their specific referential scope, continued to operate even in a divided and polarized society.

${ }^{49}$ Cf. Clark, H.H. and A. Bangerter. 2004. "Changing ideas about reference". In: Noveck, I.A. and D. Sperber (eds.). Experimental Pragmatics. p. 39. 